\title{
CARE CHARTERS
}

Simon Crompton

explains a new initiative to help

carers know what they are entitled to do.
L ast year the Government announced that it would be pressing all social services departments in England and other authorities involved in community care to publish 'community care charters'. It sees this an an extension of its commitment to a citizens charter.

The proposed charters could have major implications for carers if they are implemented properly. They should oblige authorities to provide carers with clear information about what they are entitled to. The Government says that local authorities should now be planning their own community care charters so that they can be in place by the end of 1995 . It says they should cover the following area.

- Local authorities would have to declare their commitment to providing full and accurate information, in plain language, about available services.

They would have to specify the individual's entitlement to have his or her community care needs professionally and quickly assessed, taking account of the user's own views and those of his or her carers.

- For those leaving hospital, there should be a clearly stated entitlement to a proper plan for their future before they are discharged.

- Carers will be fully involved in the arrangement made by the local authority, have their views taken into account and have a separate assessment if they want it.

- Carers and those they look after should have access to a proper complaints procedure if things go wrong, so that complaints are dealt with fairly, openly and without delay.
Authorities should give their commitment to monitoring performance against the local charter and to publish performance information so that the public can judge how services are being delivered.

All of these build on rights that carers already have. The point is that the charters may make local authorities more aware of fulfiling their duties, and carers more aware of what they are entitled to.

Some social services departments have already produced their own charters on similar lines. Health and housing authorities are also expected to comply.

Ministers have suggested that the standards set might cover the time between initial referral for assessment of needs (see 'Social services: How social services work', page 12) and the assessment being made; or between the completion of assessment and the start of services. These targets might help prevent carers and those they look after having to wait long periods for services.

A framework document for the charters was published at the end of last year, and the Government has sought views on the charters from local and health authorities, voluntary and independent providers of community care services, and organisations representing service users and carers.

If you want to find out more about community care charters in your area, contact your local social services department or Community Health Council (see 'The NHS: Your rights', page 10). 